Original Article

\title{
MICROSCOPIC, PHYSICOCHEMICAL AND PHYTOCHEMICAL SCREENING OF CRATEVA MAGNA (LOUR) DC. (LEAF)
}

\author{
ABIRAMI J. ${ }^{1}$, JOTHI G. ${ }^{1}$, BRINDHA P. ${ }^{2}$ \\ ${ }^{1}$ Department of Biochemistry, Srimad Andavan Arts and Science College, (Autonomous), Trichy, ${ }^{2}$ Associate Dean and Co ordinator, \\ CARISM, SASTRA University, Thanjavur \\ Email: prateek.jain246@gmail.com
}

Received: 22 May 2017, Revised and Accepted: 22 Jul 2017

\section{ABSTRACT}

Objective: Preliminary screening of phytochemicals is a valuable step, in the detection of the bioactive principles present in medicinal plants and subsequently may lead to drug discovery and development. In the present study, the identity, purity and strength of Crateva magna (Lour) DC. (Leaf), HPTLC, LC MS and phytochemical screening were analysed.

Methods: Tests for Identity, Purity, and Strength of Crateva magna (Lour) DC. (Leaf) Botanical standards, Physicochemical constants such as Foreign matter, Total ash, moisture content, Acid insoluble ash, and water soluble ash and Extractive value such as Hexane, Chloroform, Ethyl acetate, Alcohol were determined. The Preliminary Phytochemical Analysis of various extracts was also determined. HPTLC, LCMS ANALYSIS was analysed.

Results: Microscopic studies T S of Crateva magna leaf shows the presence of prominent midrib, upper and lower epidermis and lamina. Preliminary phytochemical analysis of dry powder and aqueous extracts of Crateva magna (Lour) DC. (Leaf) showed the presence of flavones, steroids, glycosides, sugar, alkaloids, quinones, phenols, coumarin and lignin. HPTLC of an Aqueous extract of the Crateva magna (Lour) DC. (Leaf). LC MS spectrum indicates may be the presence of bioactive compounds.

Conclusion: The results revealed that aqueous extract of Crateva magna (Lour) DC. (Leaf) has suitable for anti ulcer study.

Keywords: Alkaloids, Flavonoids, Crateva magna (Lour) DC

(c) 2017 The Authors. Published by Innovare Academic Sciences Pvt Ltd. This is an open access article under the CC BY license (http://creativecommons.org/licenses/by/4.0/) DOI: http://dx.doi.org/10.22159/ijcpr.2017v9i5.22564

\section{INTRODUCTION}

The Medicinal plants are useful for healing as well as for curing of human diseases because of the presence of phytochemical constituents. Phytochemicals are naturally occurring in the medicinal plants, leaves, vegetables, and roots that have defence mechanism and protect from various diseases. Phytochemicals are primary and secondary compounds. Chlorophyll, proteins, and common sugars are included in primary constituents and secondary compounds have terpenoid, alkaloids and phenolic compounds. Medicinal plants play a major role in meeting the medical and health needs of about $70 \%$ of populations in developed and developing countries, which serve as an important resource for the treatment of various maladies and illnesses [1].

In developing countries, there is an increasing attempt to incorporate the traditional medicines, especially herbal preparations in the local healthcare systems and modernized people are increasingly turning to herbal medicine [2]. Globally, about $85 \%$ of the traditional medicines used by different ethnic groups inhabiting various terrains for primary health care are derived from plants, especially in India; medicinal plants are widely used by all sections of the population with an estimated 7500 species of plants used by several ethnic communities [3]. The medicinal importance of a plant is due to the presence of some special substances like alkaloids, glycosides, resins, volatile oils, gums and tannins etc. The active principles usually remain concentrated in the storage organs of the plants [4].

The plant Crateva magna belonging to family Capparaceae is a well-known plant in the herbal world for its wide range of use in medicinal purposes. It is used as an anti spasmodic, hypotensive, anti inflammatory, hypoglycemic, anti protozoal, Anthelmintic, analgesic purposes. It is also used to increase appetite and for the treatment of various diseases e. g. rheumatism and nephrotoxicity, arthritis, urinary disorders [5]. The root, bark and leaf is used to treat fever, urticaria, snake bite poisoning, diseases of vatam, urinary calculi, ulcers, skin eruptions [6]. Since time immemorial medicinal plants have been in use to treat various diseases which includes peptic ulcer, cancer, diabetes, arthritis, hepatitis, acute and chronic inflammations and neurodegenerative diseases [7]. Medicinal plants are important sources for new chemical substances with potential therapeutic effects [8].

\section{MATERIALS AND METHODS}

\section{Identification and authentication}

The selected plant Crateva magna (Lour) DC. (Leaf) was collected from Places in and around Trichirappalli, identified using Flora of Presidency of Madras and authenticated by the Botanist of St. Joseph's College, Trichirappalli and a voucher specimen was deposited at RAPINAT Herbarium, Department of Botany, St. Joseph's College Trichirappalli, Tamilnadu, India.

Tests for identity, purity, and strength

\section{Determination of botanical standards [9]}

The Microscopic studies of Crateva magna (Lour) DC. (Leaf) was examined. Physicochemical constants such as Foreign matter, Total ash, moisture content, Acid insoluble ash, and water soluble ash and Extractive value such as Hexane, Chloroform, Ethyl acetate, Alcohol was determined [10]. The Preliminary Phytochemical Analysis of various extracts was also determined [11]. The HPTLC Analysis [12] and LC MS Analysis [13] also analyzed. 


\section{RESULTS AND DISCUSSION}

Microscopic analysis of Crateva magna (Lour) DC. (Leaf)
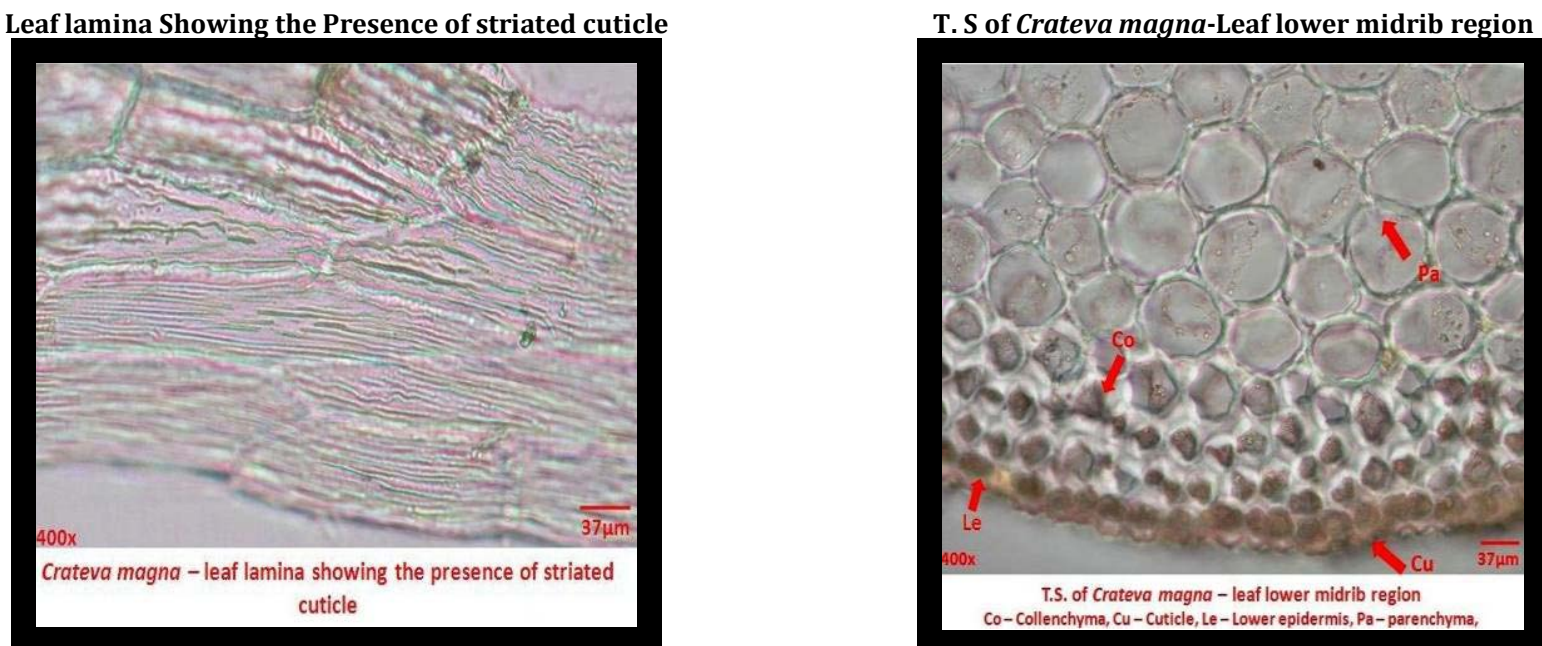

Co-collenchyma, Cu-cuticle, Le-Lower epidermis, Pa-Parenchyma

T. S of Crateva magna-Leaf midrib region

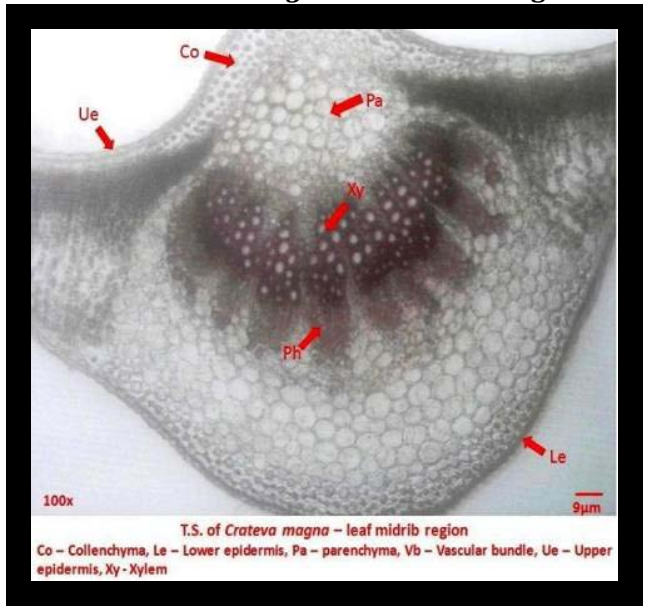

\section{T. S of Crateva magna-Leaf}

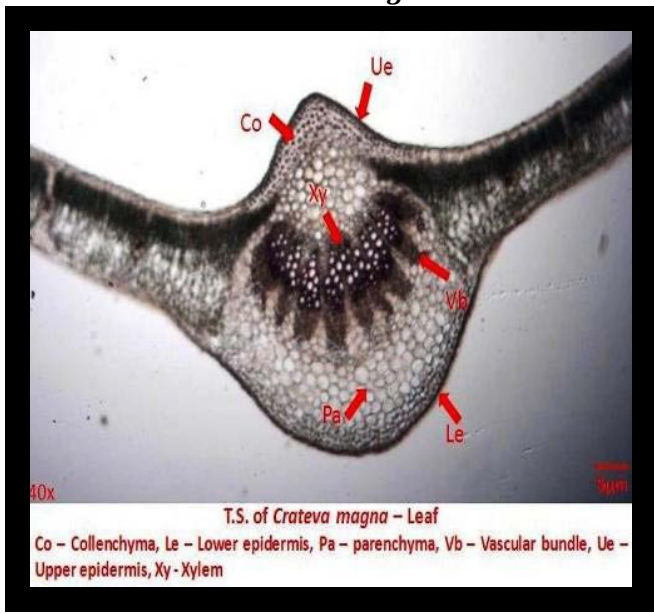

Co-collenchymas, Le-Lower epidermis, Pa-Parenchyma, Vb-Vascular bundles, Ue-Upper epidermis, Xy-Xylem, Ph-Phloem

T. S of Crateva magna-Leaf upper midrib

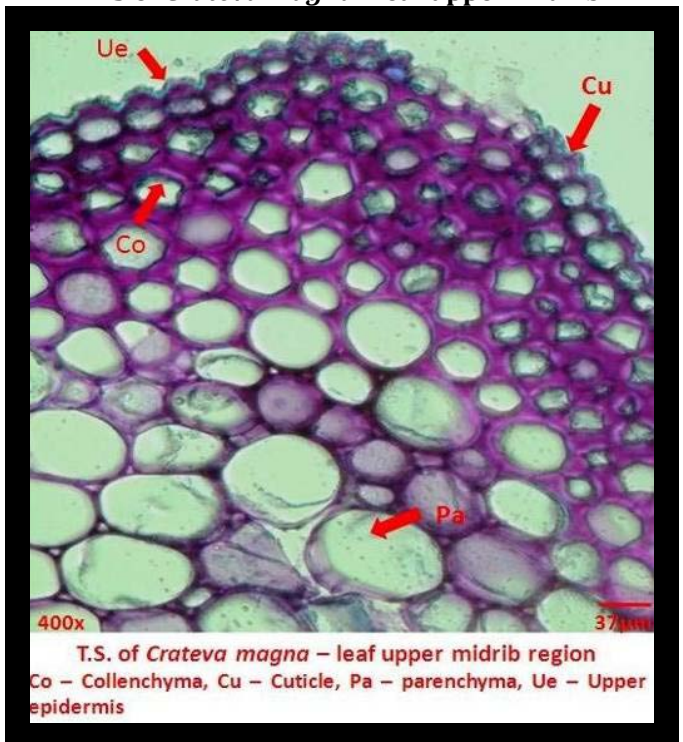

T. S of Leaf midrib region of vascular bundles

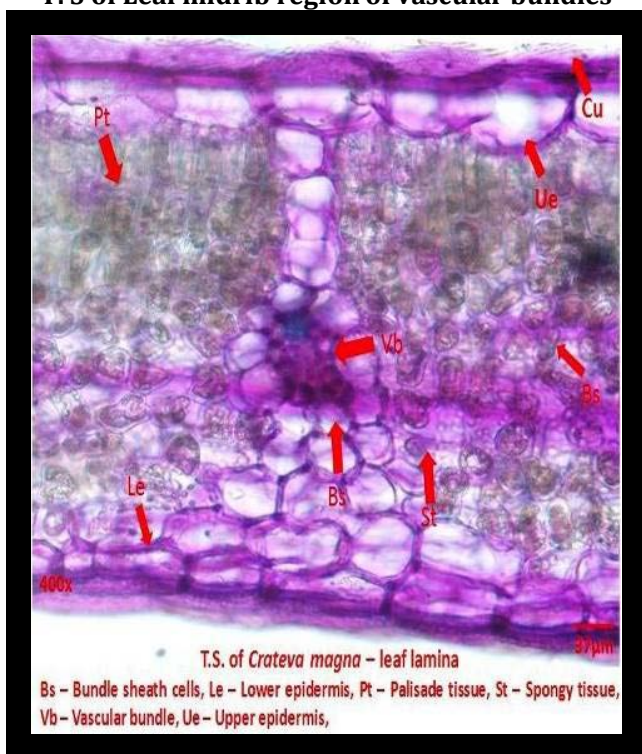

Co-collenchyma, Le-Lower epidermis, Pa-Parenchyma, Vb-Vascular bundles, Ue-Upper epidermis, Xy-Xylem, Ph-Phloem 

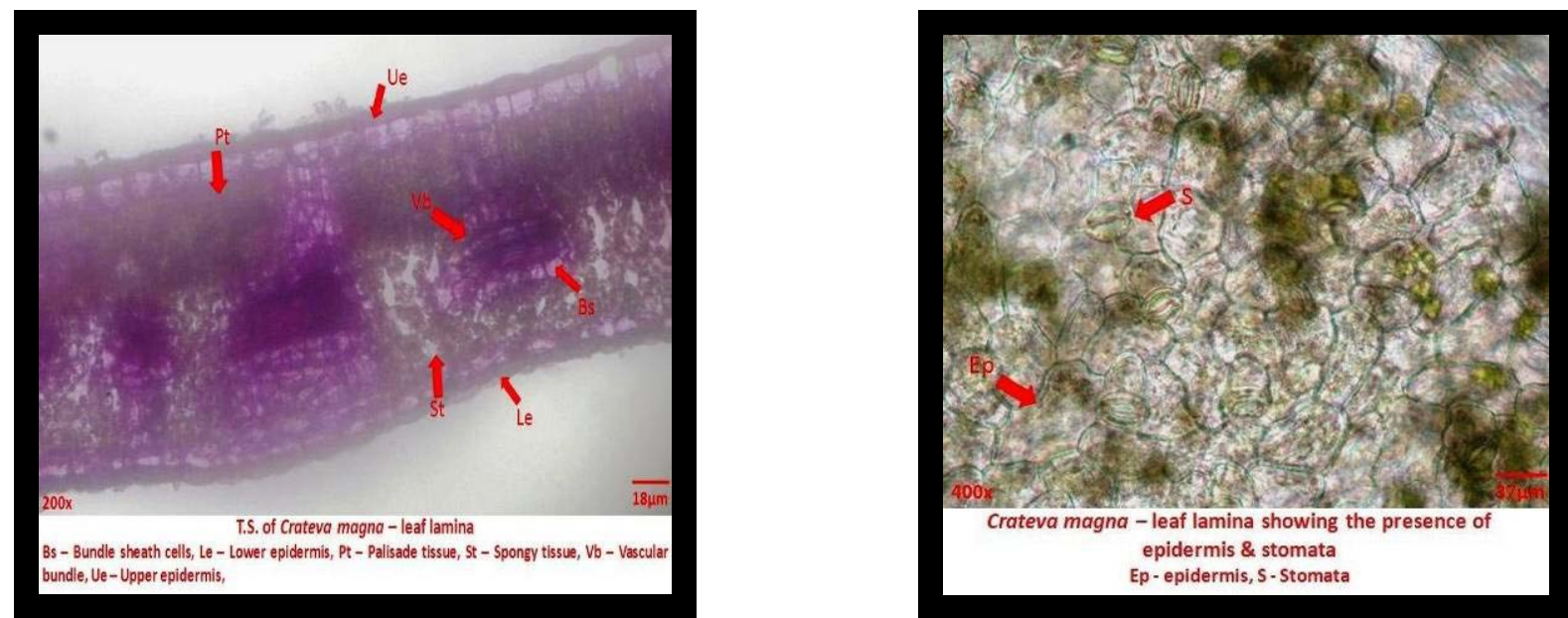

Ep-Epidermis,S-Stomata, Bs-Bundle sheath cells, Lower epidermis, Ue-Upper epidermis, St-Spongy tissues, Pt-Palisade tissues, Vbvascular bundles

Midrib T. S. of leaf showed the presence of prominent midrib, upper and lower epidermis, and lamina. The upper side of midrib was triangular in shape and the upper epidermis was made up of single layered cells and coated with thick striated cuticle. T. S. of lamina Upper epidermis was

\section{Chemical analysis}

Physicochemical constants of Crateva magna (Lour) DC. (Leaf) made up of large wide elongated parenchyma cells with thick outer cell wall and thick striated cuticle. The lower epidermis consists of narrow cells with lignified outer walls. Sub epidermis was present which was made up of parenchyma cells of varying size and shapes.

Table 1

\begin{tabular}{lll}
\hline S. No. & Parameters & Value \% W/W \\
\hline 1. & Foreign Matter & 1.3 \\
2. & Moisture Content & 1.5 \\
3. & Total Ash Content & 6.7 \\
4. & Water Soluble Ash & 6.0 \\
5. & Acid insoluble Ash & 0.7 \\
\hline
\end{tabular}

The moisture content, total ash, water soluble ash and acid insoluble ash of Crateva magna (Lour) DC. (Leaf) were given in the table 1. The total ash, water soluble ash and acid insoluble ash were found to be $6.7 \%, 6 \%$, and $0.7 \%$ respectively. The water soluble and acid insoluble ash values were well within the safety range as reported in the Indian Ayurvedic pharmacopoeia.

Determination of extractive value

Table 2: Extractive values

\begin{tabular}{lll}
\hline S. No. & Parameters & Value $\% \mathbf{~ W / W}$ \\
\hline 1. & Hexane & 0.88 \\
2. & Chloroform & 2.93 \\
3. & Ethyl acetate & 3.50 \\
4. & Alcohol & 3.20 \\
5. & Water & 6.02 \\
\hline
\end{tabular}

The water extractive value was found to be higher $(6.02 \%)$ indicated the presence of high polar compounds such as flavones, phenols, and alkaloids. The water solubility was found to be higher than the alcohol solubility.

\section{Fluorescence analysis of dry powder}

The fluorescence analysis of plant powder revealed various shades of Green and Brown under Day light. In UV light the dry powder exhibited various shades of yellow and brown fluorescence. The brown and yellow fluorescence indicated the presence of Alkaloids and Flavonoids. The green fluorescence indicated the presence of Sterols.

\section{Preliminary phytochemical screening of drug}

Preliminary Phytochemical analysis of various extracts showed the presence of flavones in chloroform and Ethyl acetate extracts. Ethanol, Chloroform, and Ethyl acetate extracts showed the presence of Alkaloids. Phenol was found to be present in Ethanol, Chloroform and Ethyl acetate extracts. Hexane and Ethyl acetate extracts showed the presence of coumarin. Lignin was found to be absent in all the extracts.

Preliminary phytochemical analysis of dry powder and aqueous extract of Crateva magna (Lour) DC. (Leaf) showed the presence flavones, steroids, glycosides, sugar, alkaloids, quinones, phenols, coumarin and lignin. 


\section{TLC, HPTLC Profiles of Crateva magna (Lour) DC. (Leaf)}

Stationary phase: Silica Gel 60 F254

Mobile phase: Toluene: Ethyl acetate: Diethyl amine (7:2:1)

Wavelength: $366 \mathrm{~nm}$

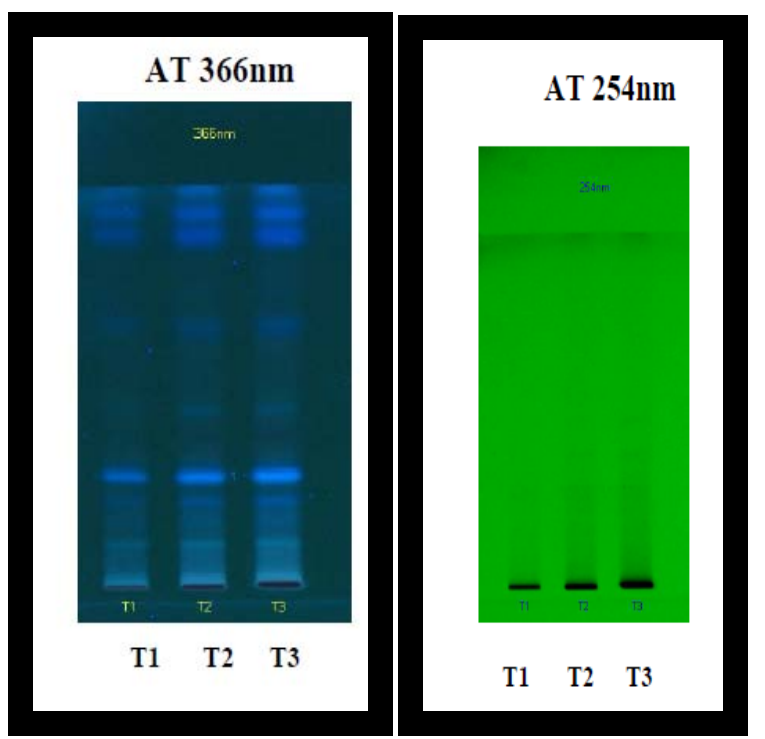

Use of high-performance liquid chromatograms, thin-layer chromatography, atomic absorption spectroscopy, gas chromatography and where necessary more sophisticated techniques such as NMR and LC/MS has now become common in complementary medicines manufacturing industries to ensure the quality of plant materials and final product [14]. The emphasis on good manufacturing practice has steadily increased over years. This spectrum indicates may be the presence of bioactive compounds.

\section{CONCLUSION}

In Microscopic studies, $\mathrm{T}$ S of Crateva magna leaf showed the presence of prominent midrib, upper and lower epidermis and lamina. The upper side of midrib is triangular in shape and the upper epidermis is made up of single layered cells and coated with thick striated cuticle. Preliminary phytochemical analysis of dry powder and aqueous extracts of Crateva magna (Lour) DC. (Leaf) showed the presence flavones, steroids, glycosides, sugar, alkaloids, quinones, phenols, coumarin and lignin. HPTLC of an Aqueous extract of the Crateva magna (Lour) DC. (Leaf) on Silica gel 60F254 using Toluene: Ethyl acetate: Diethyl amine $(7: 2: 1)$ as the mobile phase. Under UV $366 \mathrm{~nm}$ five spots appear at Rf values $0.04,0.09,0.16,0.22,0.33$. LC MS spectrum indicated may be the presence of bioactive compounds such as alkaloids, Flavonoids, glycosides, terpenoids, and tannins. The results revealed that aqueous extract of Crateva magna (Lour) DC. (Leaf) has suitable for anti ulcer study.

\section{ACKNOWLEDGEMENT}

The authors wish to thank the University Grant Commission (UGC) for providing financial assistance under the scheme of Minor Research Project [No: F. MRP-6104/15 (SERO/UGC)], Hyderabad, Government of India.

\section{CONFLICT OF INTERESTS}

Declared none

\section{REFERENCES}

1. Ngari EW, Chiuri LW, Kariuki ST, Huckett S. Ethnomedicine of ogiek of river Njoro Watershed. Ethnobot Res Aplications 2010;8:135-52.

2. Njoroge GN, Bussmann RW. Ethnotherapeutic management of skin diseases 80 ISSN: 2229-3469 (Print) AR Florence. Among the Kikuyus of Central Kenys. J Ethnopharmacol 2007;111:303-7.

3. Farnsworth NR. Preliminary phytochemical screening and HPLC analysis of flavonoid from the methanolic extract of leaves of Annona squamosa. Screening plants for new National Academy Press: Washington, DC; 1988. p. 83-97.

4. Himesh S, Sarvesh S, Sharan PS, Mishra K. Preliminary phytochemical screening and HPLC analysis of flavonoid from the methanolic extract of leaves of Annona squamosa. Int Res J Pharm 2011;5:242-6.

5. Shirwaikar A, Setty M, Bommu P. Effect of lupeol isolated from Crataeva nurvala Buch Ham stem bark extract against free radical induced nephrotoxicity in rats. Indian J Exp Biol 2004;42:686-90.

6. A book of Medicinal plants by S. N Yoganarasimhan, Tamilnadu; 2000. p. 159.

7. Govindarajan, Vijayakumar M, Pushpangadan P. "Antioxidant approach to disease management and the role of 'Rasayana herbs of Ayurveda". J Ethnopharmacol 2005;99:165-78.

8. Wahida B, Abderrahman B, Nabil C. Antiulcerogenic activity of Zizyphus lotus (L) extracts. J Ethnopharmacol 2007;112:228-31.

9. Sass JE. Elements of botanical microtechnique. MC Graw Hill Book Co. Newyork; 1940. p. 222.

10. Anonymous. The Ayurvedic pharmacopoeia of India, Government of India, Ministry of Health and Family welfare, Department of Indian system of medicine and Homeopathy, New Delhi; 2001;1:142-3.

11. Harborne JB. Phytochemical methods, a guide to modern technique of plant analysis. $2^{\text {nd }}$ edition. Chapman and Hall UK; 1991. p. 72.

12. Harborne JB. Phytochemical methods, a guide to modern technique of plant Analysis. New york: Chapman and Hall; 1984. p. 1-89.

13. Figueirinha A, Paranhos A, Perez-Alonso JJ. Cymbopogon citratus leaves: characterization of flavonoids by HPLC-PDAESI/MS/MS and an approach to their potential as a source of bioactive polyphenols. Food Chem 2008;110:718-28.

14. Rosenbloom RA, Chaudhary J, Castro-Eschenbach D. Traditional botanical medicine: an introduction. Am J Ther 2011;18:158-61.

How to cite this article

- Abirami J, Jothi G, Brindha P. Microscopic, physicochemical and phytochemical screening of Crateva magna (lour) DC. (leaf). Int J Curr Pharm Res 2017;9(5):201-204 